\title{
Genetic Diversity among Geographically Separated Cyperus rotundus Accessions Based on RAPD Markers and Morphological Characteristics
}

\author{
William T. Molin ${ }^{1 *}$, Richard R. Kronfol ${ }^{2}$, Jeffery D. Ray ${ }^{3}$, Brian E. Scheffler ${ }^{4}$, Charles T. Bryson ${ }^{1}$ \\ ${ }^{1}$ Crop Production Systems Research Unit, USDA-ARS, Stoneville, MS, USA \\ ${ }^{2}$ Virginia Mason Medical Center, Seattle, WA, USA \\ ${ }^{3}$ Crop Genetics Research Unit, USDA-ARS, Stoneville, MS, USA \\ ${ }^{4}$ Genetics and Bioinformatics Research Unit, USDA-ARS, Stoneville, MS, USA \\ Email: *william.molin@u sda.gov, rkron @@gmail.com, jeff.ray@usda.gov, brian.scheffler@usda.gov, dr.sedge@gma il.com
}

How to cite this paper: Molin, W.T., Kronfol, R.R., Ray, J.D., Scheffler, B.E. and Bryson, C.T. (2019) Genetic Diversity among Geographically Separated Cyperus rotundus Accessions Based on RAPD Markers and Morphological Characteristics. American Journal of Plant Sciences, 10, 2034-2046.

https://doi.org/10.4236/ajps.2019.1011143

Received: October 8, 2019

Accepted: November 18, 2019

Published: November 21, 2019

Copyright $\odot 2019$ by author(s) and Scientific Research Publishing Inc. This work is licensed under the Creative Commons Attribution International License (CC BY 4.0).

http://creativecommons.org/licenses/by/4.0/

\section{(c) (i) Open Access}

\begin{abstract}
The diversity of globally distributed populations of purple nutsedge was assessed using molecular marker data and morphological traits. Cluster analysis of binary random amplified polymorphic DNA (RAPD) data and morphological traits indicated that the global population of purple nutsedge consisted of two clades. Cluster analysis of the RAPD data supported separation of the purple nutsedge accessions evaluated into two distinct clades of 11 and 33 accessions. Except for accessions identified as California* and Arizona, all USA accessions were clustered with accessions from Taiwan, Western Samoa, New Zealand, Malaysia, Japan, El Salvador, Columbia, Australia, Thailand and West Indies. A second cluster included accessions from Sudan, Greece, Iran, California $^{*}$, Arizona, Brazil, Argentina, Mauritius, Philippines, Indonesia and Tanzania. The accessions from Sudan, Greece, Iran, Mauritius, and Tanzania were distributed along a similar longitudinal axis. Cluster analysis based on morphological traits though not identical to that based on RAPD data also supported separation into two clades and perhaps a third. The lack of genetic diversity among accessions supported the hypothesis that spread and propagation into new environments were largely by tubers which preserved genetic identity. The lack of diversity particularly among New World and USA accessions may also reflect a relatively recent introduction of the species into the Americas and a low level of outcrossing.
\end{abstract}

\section{Keywords}

Purple Nutsedge, RAPDs, Genetic Diversity 


\section{Introduction}

Purple nutsedge (Cyperus rotundus $\mathrm{L}$.) is an important agricultural weed in the tropical and warm temperate regions of the world [1]. It has been found on six continents, in 92 countries and is a problematic weed in 52 crops [1] [2]. Historically, purple nutsedge was a beneficial species valued for its medicinal uses, aromatic qualities, and as a source of carbohydrates and fiber [3]. Its use as a food or as an agent to reduce dental plaque date back to $15,000 \mathrm{BC}$ based on Cyperus starch granules isolated from the teeth of skeletal remains unearthed in an ancient Sudanese burial site [4]. The utility of purple nutsedge may account for its spread throughout the eastern Mediterranean region and Eurasia. Hence the country of origin of purple nutsedge is uncertain [5] [6].

Purple nutsedge might be expected to be genetically and morphologically diverse considering its worldwide distribution. Purple nutsedge, however, which rarely produces viable seeds, spreads vegetatively by rhizomes and tubers [7] resulting in clonal populations exhibiting limited gene flow and diversity [1] [7] [8]. Furthermore, the genetic identity of purple nutsedge populations may also be conserved in time because tubers buried deep in the soil profile may remain dormant for up to 42 months only to resume growth when favorable conditions return [9] [10].

Traditional morphological taxonomy recognizes diversity among purple nutsedge populations. Over 30 varieties of C. rotundus were listed in Tropicos [11] but a more recent revision of the genus subdivided the species into eight varieties and four subspecies based on morphology [5]. Morphological variation among 34 purple nutsedge accessions from 20 countries and 14 states in the USA has been reported [12]. The variable traits measured included: plant habit; number of shoots, involucral bracts and culms; number of leaves per shoot; leaf color, shape and size; inflorescence color and shape; spikelet number; rachis length and number; and tuber size, texture, and shape [12]. The variations among accessions were greater for those accessions from geographically distant locations compared to those within the continental USA [12]. Although morphological variation may be an indicator of genetic diversity, plasticity among morphological traits in C. esculentus has been shown to vary with growth under different environmental conditions [13]. Morphological plasticity was observed in $C$. esculentus in the number of spikelets per spike, spikelet length and width, ray length, culm width and bract length, traits commonly used for taxonomic diversification [13]. Hence, to better assess genetic relatedness between purple nutsedge accessions, alternative methods for comparing accessions from diverse locations would be helpful.

Diversity among regional collections of purple nutsedge accessions has been determined by analysis of molecular data from random amplified polymorphic DNA (RAPDs) sesquiterpene profiles of the essential oils in tuber extracts and isozyme patterns [14] [15] [16]. These studies have focused on populations from a few neighboring countries with an occasional outlying country. Okoli et al. 
[14] used RAPD markers to explore genetic differences among accessions from across the southern USA, Caribbean Islands, Brazil including one accession from India. They found no differences among 18 accessions from the southern USA, Puerto Rico, Virgin Islands and West Indies and two out of four accessions from Brazil. Two other Brazilian accessions formed a second group and a single accession from India formed a third. Genetic variability based on RAPD markers among purple nutsedge accessions from Brazil (66 accessions), Florida ( 3 accessions), Hawaii ( 2 accessions), Mexico ( 1 accession), and a globally distant accession from Israel indicated the existence of distinctive intraspecific biotypes and the similarity decreased as geographical separation increased [15]. Komai et al. [16] identified four major chemotypes of C. rotundus, from the Pacific Rim and Basin. These were designated as $\mathrm{O}, \mathrm{M}, \mathrm{H}$, and $\mathrm{K}$, based on essential oils in tubers. $\mathrm{H}, \mathrm{M}$ and $\mathrm{O}$ types were found in Asia. $\mathrm{O}$ type had the broadest range from Asia to the Americas, $\mathrm{K}$ type dominated in the Hawaiian Islands and Mexico, $\mathrm{H}$ type was only found in Japan and southern Asian islands and type $M$ was found in Japan and more northern Asian areas. The chemotype data indicated separation based on gene products rather than genes themselves. Isozyme markers identified 10 different biotypes of C. rotundus from 66 sites in Brazil [17]. However, differences among accessions in these studies were based on visual determinations.

Cluster analysis of morphometric, isozymic and RAPD patterns separated purple and yellow nutsedge and a possible hybrid between the two species [18]. The authors speculated that the hybrid may have been a sexually reproducing form of purple nutsedge [18], a conclusion also presented by Okoli [14]. Cluster analysis based on microsatellite DNA marker data was also applied to 12 purple nutsedge accessions collected by Wills [12] and yellow nutsedge [19]. Four accessions were from the USA and 8 were from outside of the USA. Yellow nutsedge was clearly separated from the purple nutsedge accessions and the purple nutsedge was divided into 3 clusters [19]. In this study, Brazil was grouped with Indonesia, Sudan was with Greece, and Taiwan, Thailand Australia and El Salvador were grouped with the USA accessions the microsatellite markers represent a new group of markers for separation of nutsedge accessions which may offer an additional estimation of genetic relationships to those reported with binary data from RAPDs. Taken together, these studies indicated that genetic variants exist among purple nutsedge populations.

The genetic and morphological diversity between purple nutsedge accessions has not been examined on a larger global sample. The Wills [12] purple nutsedge collection represents 20 countries and 14 states in the USA and has been maintained except for the loss of the one accession from Israel, and the number of USA accessions has been increased by ten. The objectives of this research were to determine the diversity of purple nutsedge from these widely dispersed, geographically distant locations by analysis of genetic distances based on binary data from molecular markers and morphological traits. 


\section{Materials and Methods}

The Wills [19] purple nutsedge collection and an additional ten accessions made by WTM from across the southern United States and a yellow nutsedge (C. esculantus) accession from Mississippi, were used in this study (Table 1). The Wills [19] collection followed Tropicos [11] descriptions and all accessions were determined as " $C$. rotundus L." by T. G. Koyama (The New York Botanical Gardens, 2900 Southern Blvd., Bronx, NY 10458-5126 USA) and S. McDaniel (Institute of Botanical Exploration, Box EN, Mississippi State, MS 39762 USA). Herbarium vouchers for this collection were deposited at the Mississippi Museum of Natural Science, Jackson, MS, USA and are now available thru the SERNEC network web site [20]. Accessions in bold font followed by an asterisk were collected ten years after the Wills collections (Table 1).

Purple nutsedge accessions were grown in 3.8-liter pots filled with a 1:1 mixture of soil (Dundee silt clay loam) and growth mix (Ready Earth plug and seedling mix, Sun Gro Horticultural Distribution Inc., 15,831 NE $8^{\text {th }}$ St., Suite 100 , Bellevue, WA 98008). Plants were placed in a greenhouse with $35^{\circ} \mathrm{C} / 30^{\circ} \mathrm{C}$ day/night temperature $\left( \pm 2^{\circ} \mathrm{C}\right)$ and a $14 / 10 \mathrm{~h}$ day/night light regime supplemented with high pressure sodium lamps to maintain a 14-hour photoperiod. Pots were irrigated as necessary and fertilized with complete fertilizer (Osmocote 15-9-12, Scotts Sierra Horticultural Products Co., 14111 Scottslawn Rd., Marysville $\mathrm{OH}$ 43041).

To assess genetic variability, DNA from each of the purple nutsedge accessions was isolated and used in PCR with the primers in Table 1. The PCR products were separated on gels and scored for the presence (1) or absence (0) of PCR products. The resulting binary data were subjected to cluster analysis.

DNA was extracted from leaf tissue using a modified CTAB (cetyltrimethylammonium bromide) procedure [21]. Mature purple nutsedge leaves were cut into 3 -cm fragments and freeze-dried overnight. The resulting tissue was ground into powder in a $50 \mathrm{~mL}$ tube using mechanical agitation with $1-\mathrm{cm}$ diameter steel beads. DNA was extracted from $50 \mathrm{mg}$ of dry tissue in a $1.5-\mathrm{mL}$ tube by rapidly shaking in the presence of a steel bead in $500 \mu \mathrm{L}$ of extraction buffer (20 mM CTAB, 20 mM PVP, $10 \mathrm{mM}$ O-phenanthrolene, $1.4 \mathrm{M} \mathrm{NaCl}, 20 \mathrm{mM}$ EDTA, $100 \mathrm{mM}$ Tris- $\mathrm{HCl}$, and $80 \mathrm{mM} \beta$-mercaptoethanol). The homogenate was then incubated for $1 \mathrm{~h}$. Following incubation, samples were placed on ice for $10 \mathrm{~min}$, then clarified by centrifugation at $20,000 \times \mathrm{g}$ for $5 \mathrm{~min}$ at $25^{\circ} \mathrm{C}$. The resulting supernatant was mixed with an equal volume of 5:1 phenol/chloroform and mixed extensively by inversion. Organic and aqueous phases were separated using Phase-Lock gel (Eppendorf, Hauppauge, NY). The aqueous phase was transferred into a new tube, and DNA was precipitated in isopropyl alcohol, washed with $75 \%$ ethanol, and air-dried before it was dissolved in Tris/EDTA (20 $\mathrm{mM} / 100 \mathrm{mM}$ ) buffer. Genomic DNA was quantified by spectrometry and the DNA was diluted to a final concentration of $20 \mathrm{ng} \cdot \mu \mathrm{L}^{-1}$.

The PCR reaction mix contained: $1 \times$ JumpStart RedTaq Ready Mix (Sigma-Aldrich, St. Louis, MO), $2 \mathrm{ng} \cdot \mu \mathrm{L}^{-1}$ genomic DNA, and a primer concentration 
Table 1. Accessions of purple nutsedge used in RAPD analysis. Accession numbers correspond to the lanes in Figure 1. Accessions in bold font followed by an asterisk were collected by WTM and all others were from Wills [12] collection. Numbers following the state of origin indicate that more than 1 representative came from that state. Wills [12] only presented data from one individual from each state.

\begin{tabular}{cccccc}
\hline Accession \# & Origin & Accession \# & Origin & Accession \# & Origin \\
\hline 01 & South Carolina $^{*}$ & 18 & Japan & 35 & Georgia-2 \\
02 & Mississippi $^{*}$ & 19 & Iran & 36 & Arkansas \\
03 & California $^{*}$ & 20 & Indonesia & 37 & Mississippi \\
04 & Georgia $^{*}$ & 21 & Greece & 38 & Louisiana \\
05 & Arizona $^{*}$ & 22 & El Salvador & 39 & North Carolina \\
06 & North Carolina $^{*}$ & 23 & Columbia-1 & 40 & South Carolina \\
07 & Hawaii* & 24 & Columbia-2 & 41 & Thailand \\
08 & New Mexico* & 25 & Brazil & 42 & West Indies \\
09 & Louisiana* & 26 & Australia & 43 & Puerto Rico \\
10 & Alabama & 27 & Florida-1 & 44 & Tanzania \\
11 & Yellow Nutsedge MS & 28 & Argentina & 45 & Tennessee \\
12 & Taiwan & 29 & Texas-1 & 46 & Western Samoa \\
13 & Sudan & 30 & Texas-2 & 47 & Florida-2 \\
14 & Philippines & 31 & Tennessee & 48 & Hawaii \\
15 & New Zealand & 32 & New Mexico & 49 & Alabama \\
16 & Mauritius & 33 & Louisiana & 50 & California-1 \\
17 & Malaysia & 34 & Georgia-1 & 51 & California-2 \\
\hline
\end{tabular}

of $3 \mu \mathrm{M}$ for either OPB17, OPB18, OPB14, OPC2, OPB1, OPB7, and OPC8 or $0.4 \mu \mathrm{M}$ for primers OPG17, OPH18, OPI7, OPI12, OPL7 and OPN6 (Operon Technologies, Alameda, CA) (Table 2). The PCR amplification protocol consisted of a $2 \mathrm{~min}$ incubation at $95^{\circ} \mathrm{C}$, followed by 40 cycles of $94^{\circ} \mathrm{C}$ for $30 \mathrm{sec}$, $42^{\circ} \mathrm{C}$ for $30 \mathrm{sec}, 72^{\circ} \mathrm{C}$ for $1 \mathrm{~min}$; and a final extension cycle at $72^{\circ} \mathrm{C}$ for $5 \mathrm{~min}$. Amplification products were resolved on a $1.5 \%$ agarose gel consisting of a 1:1 mixture of low EEO agarose and low melting agarose in neutral electrophoresis buffer (100 mM Tris, $1 \mathrm{mM}$ EDTA, and $12.4 \mathrm{mM}$ sodium acetate adjusted to $\mathrm{pH}$ 8.1). Gels were run at $24 \mathrm{~V}$ for 16 - 18 hours, then stained in a $0.00004 \%$ ethidium bromide solution for 30 minutes prior to visualization and photography with an AlphaImager 3300 transilluminator (Alpha Innotech Inc., Kasendorf, Germany).

Where there was more than one accession from a state or country only the RAPD data from one accession was used because the data was identical for both accessions. PCR data from Iran and yellow nutsedge were not included in the cluster analysis because these data were not present in the morphological data set. Amplification products from primers ranged from 100 to 600 base pairs and scored as either present (1) or absent (0) for all accessions. PROC CLUSTER 
Table 2. Sequence of decamer primers used in random amplified polymorphic DNA PCR.

\begin{tabular}{cl}
\hline Operon Primers & Sequence 5' to 3' \\
\hline OPB1 & GTTTCGCTCC \\
OPB7 & GGTGACGCAG \\
OPB14 & TCCGCTCTGG \\
OPB17 & AGGGAACGAG \\
OPB18 & CCACAGCAGT \\
OPC2 & GTGAGGCGTC \\
OPC8 & TGGACCGGTG \\
OPG17 & CACTCTCCTC \\
OPH18 & GAATCTCCTC \\
OPI7 & CAGCGACAAG \\
OPI12 & AGAGGGCACA \\
OPL7 & AGGCGGGAAG \\
OPN6 & GAGACGCACA \\
\hline
\end{tabular}

(SAS 2012) using Ward's minimum variance method was used to analyze the distance matrix among accessions and tree diagrams were generated with PROC TREE (SAS 2012) [22]. The data were also subjected to principle component analysis in SAS and a plot was constructed from the principle components 1 and 2 [22].

Wills reported measurements of morphological traits for each of the purple nutsedge accessions in his collection [12]. These included measurements of plant habit; number of shoots, involucral bracts and culms; number of leaves per shoot; leaf color, shape and size; inflorescence color and shape; spikelet number; rachis length and number; and tuber size, texture, and shape [12]. These values were normalized according the formula: $\mathrm{X}_{\text {new }}=\left(\mathrm{X}-\mathrm{X}_{\min }\right) /\left(\mathrm{X}_{\max }-\mathrm{X}_{\min }\right)$ to create a range of values from 0 to 1 to perform cluster analysis. $X_{\max }$ and $X_{\min }$ were the maximum and minimum values for each trait, $X$ was the actual value, and $X_{\text {new }}$ was the newly calculated value from the original data. Cluster analysis was performed as previously described with $\mathrm{X}_{\text {new }}$ data.

\section{Results}

Multiple PCR amplification products were obtained from only 13 (Table 2) of 240 primers initially screened with 5 accessions (data not shown). These results indicated that primer selection was essential for comparative PCR analysis of purple nutsedge accessions as was presented by Okoli et al. [14]. The PCR amplification products with primer G-17 are shown in Figure 1. There were four bands comprised of approximately 110, 170, 280 and 380 bases which were common to all US and ex-US accessions. Amplification products from the yellow nutsedge accession (column 11, Figure 1) were included to verify that the 


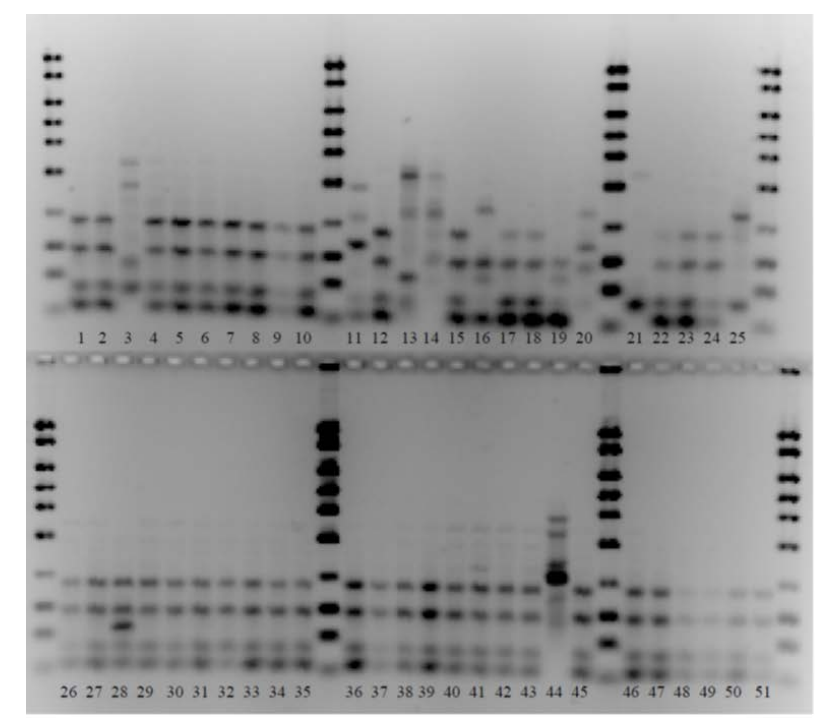

Figure 1. RAPD patterns for 50 purple nutsedge and 1 yellow nutsedge accession using an oligonucleotide primer G-17. DNA ladders $(1 \mathrm{~Kb})$ are in lanes adjacent to lanes 1, 10, 20, 25, 263545 and 51. All other lanes consist of nutsedge PCR products ordered sequentially by accession number from Table 1 .

molecular markers could differentiate among nutsedge species. Bands at 110 and 170 bases were present in yellow nutsedge and the 3 higher molecular sized bands were different from those in purple nutsedges indicating that these markers could separate species. However, bands at similar positions may not indicate similar sequence.

Cluster analysis of the RAPD data based only on the Wills [12] collection indicated that purple nutsedge may be divided into two clades spread across large geographical areas (Figure 2). Five of the eight accessions in cluster \#2 were associated along a similar longitude (Sudan, Greece, Iran, Mauritius and Tanzania) possibly indicating a common origin. The larger cluster (group 1) consisted largely of US and New World accessions as well as several from Asia, Indian Ocean, and the Pacific Rim countries.

When the more recently collected US accessions were included in the cluster analysis (Figure 3 ) with the Wills accessions, California* and an Arizona accession clustered with accessions from Sudan, Greece, Iran, Brazil, Argentina, Mauritius, Philippines, Indonesia and Tanzania. That Brazil clustered with these may indicate that it also originated from a similar Afro-Eurasian location. Except for California ${ }^{*}$ and Arizona, all of the more recently collected US accessions clustered together and were separated from most of the US accessions previously collected by Wills [12].

Cluster analysis based on morphological data from the Wills [12] collection indicated that purple nutsedge may be divided into two or possibly three clades spread across large geographical areas (Figure 4). Accessions from Philippines Japan, Thailand and Malaysia and those from Sudan and Tanzania were also associated regionally and may indicate a similar origin. 


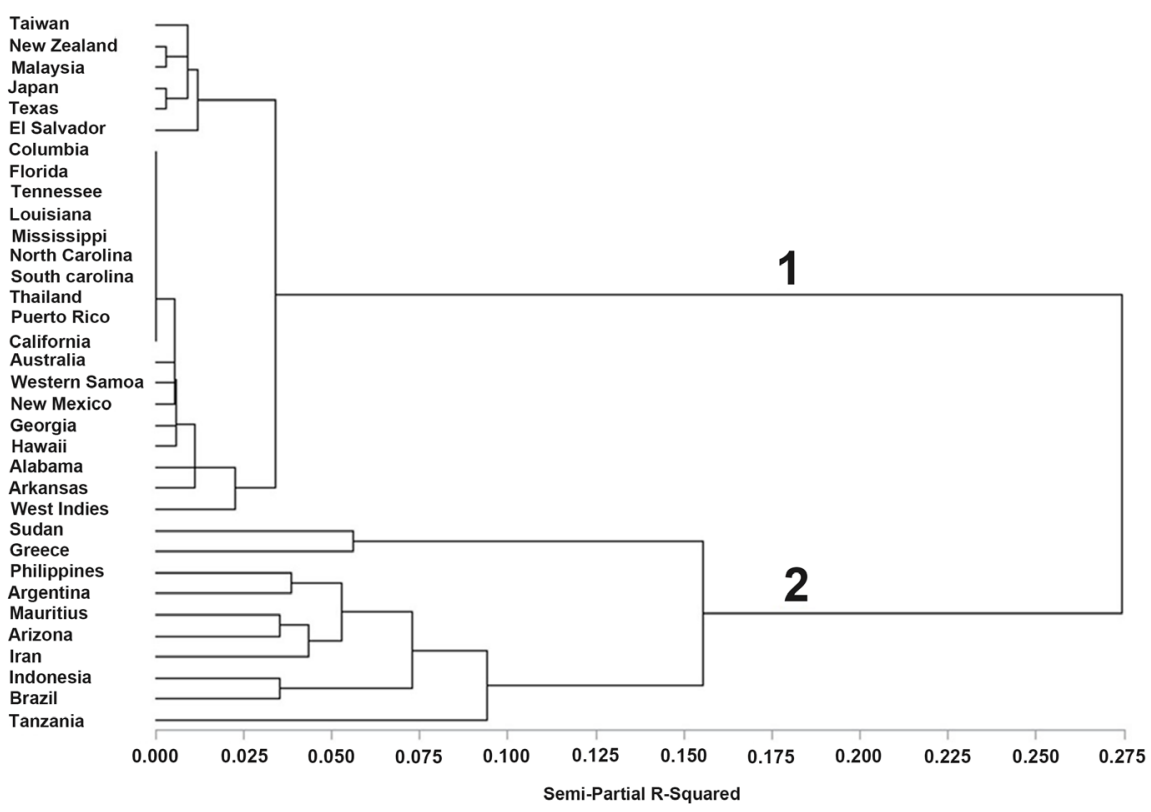

Figure 2. Dendrogram of purple nutsedge accessions from around the world based upon random amplified polymorphic DNA analysis using the modified Ward's distance method. Clusters are indicated by numbers.

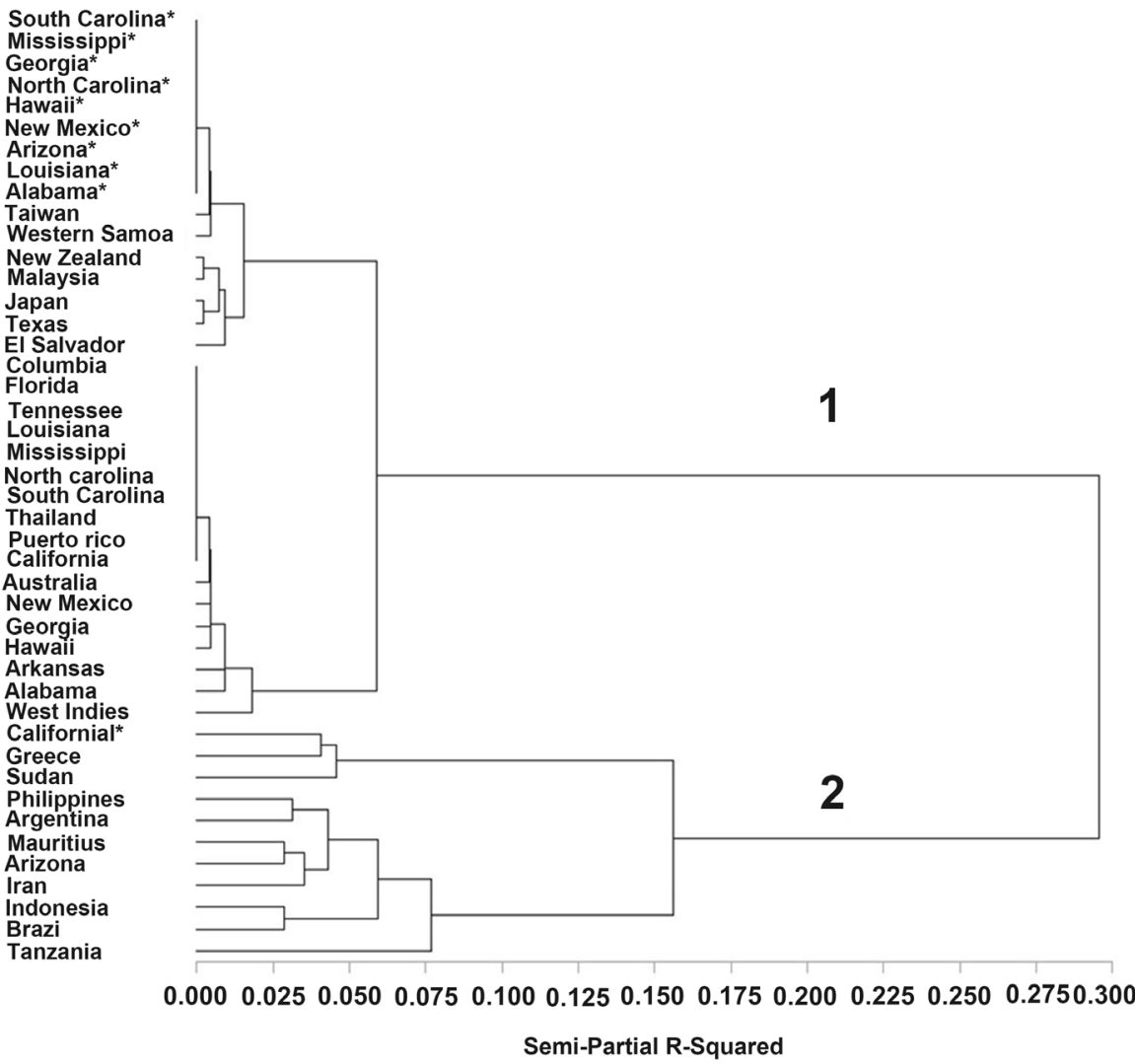

Figure 3. Dendrogram of purple nutsedge accessions from around the world based upon random amplified polymorphic DNA analysis using the modified Ward's distance method. Clusters are indicated by numbers. Accessions followed by an asterisk were collected by WTM and the others were by Wills [12]. 


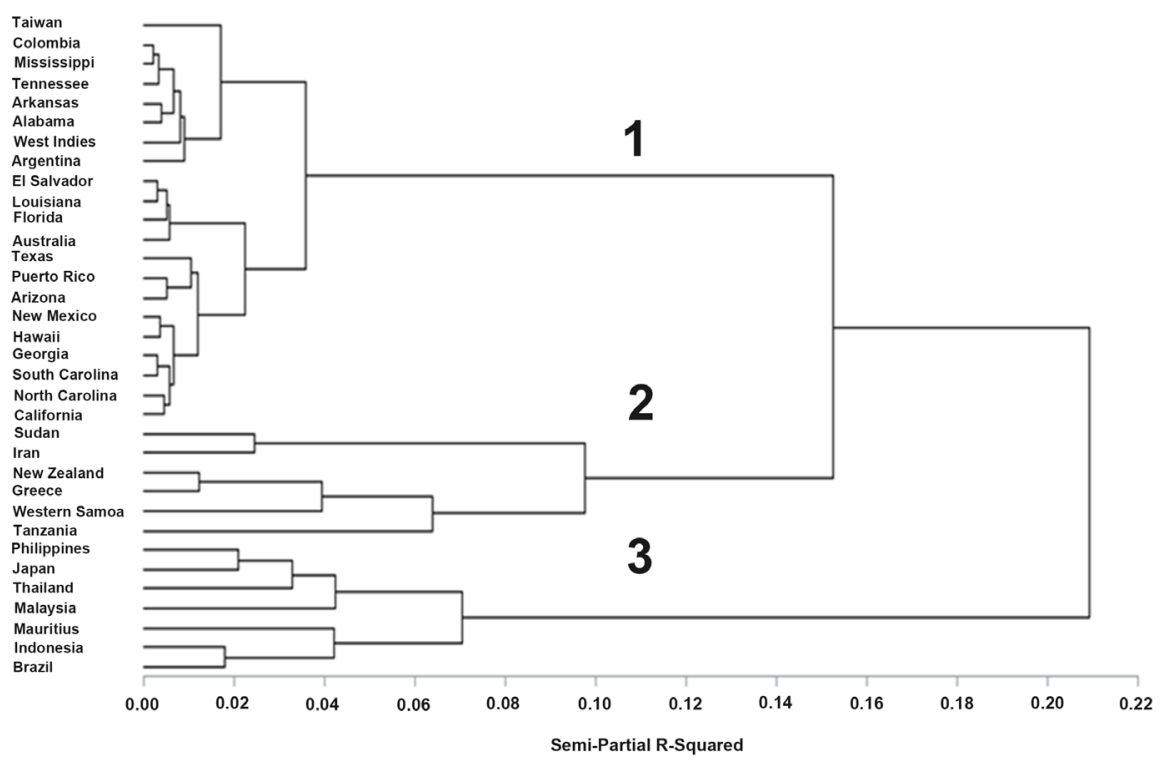

Figure 4. Dendrogram of purple nutsedge accessions from around the world based upon morphological traits using the modified Ward's distance method.

A plot of the first and second coordinates derived from principal component analysis of molecular marker data also supported genetic divergence among the accessions and the possibility of a third cluster (Figure 5). Accessions with rectangular coordinates greater than zero formed a large cluster composed of all US accessions, several Central American accessions, and accessions from Taiwan, New Zealand, Indonesia, Western Samoa and Australia. A second cluster, with a positive coordinate from principle component 1 and a negative coordinate from principle component 2, was composed of accessions from Sudan, Greece, and Tanzania. The third cluster had negative values for both rectangular coordinates and was composed of accessions from Malaysia, Thailand, Philippines, Japan and Brazil and perhaps Mauritius and Argentina.

\section{Discussion}

Prior to any evaluation of traits, these accessions were verified by morphological traits to be C. rotundus. Cluster analysis of RAPD scores provided further evidence for there being geographic variants among purple nutsedge accessions indicating that with time isolation may lead to speciation. Results from previous studies also indicated limited geographic variations among purple nutsedge accessions [14]-[18]. Okoli et al. [14] reported that there were no differences among seven samples of purple nutsedge obtained from the US. Results from gene product analyses, such as chemotyping and isozyme analysis, in conjunction with the molecular and morphological trait analyses, supports the recognized separation of purple nutsedge into several subspecies and varieties [5]. However, missing from all simultaneous analyses on morphology, genetics and biochemistry for large populations collected from geographically separated regions. 


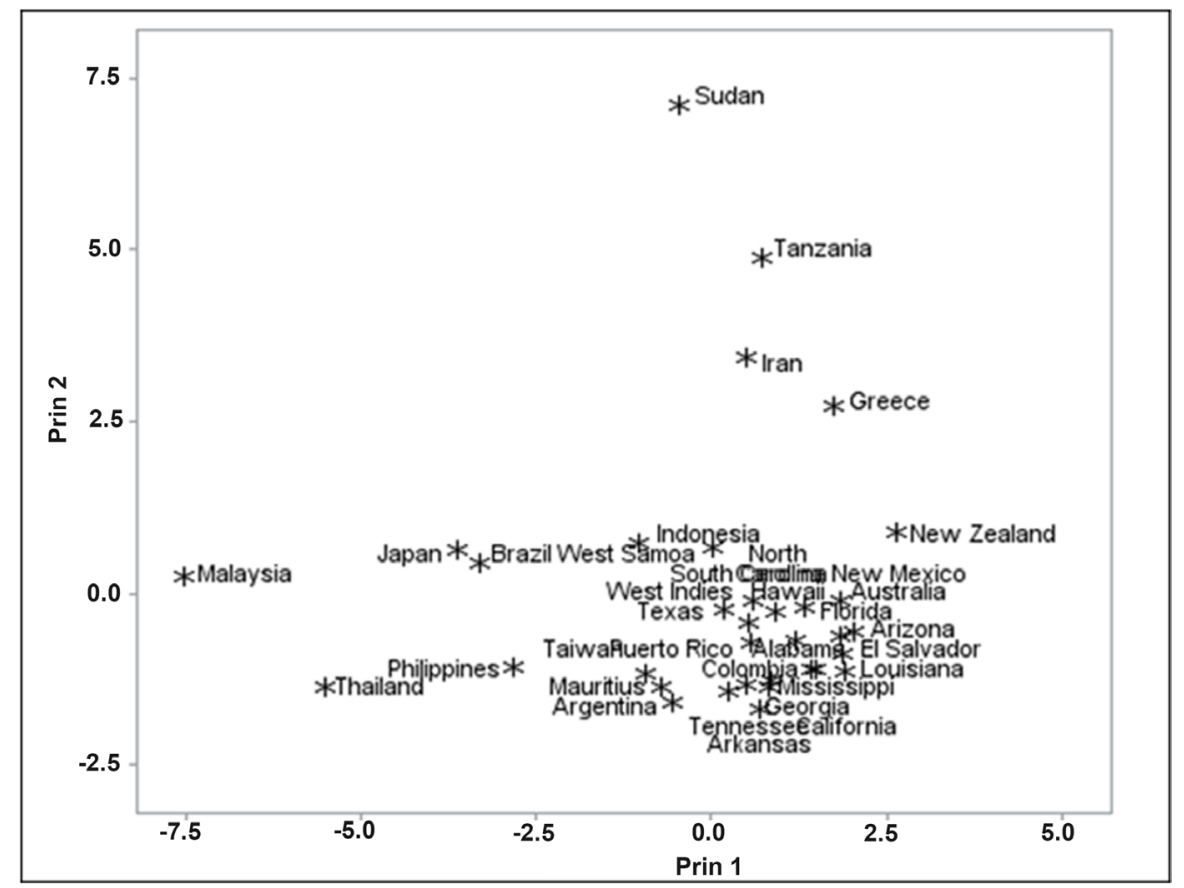

Figure 5. Plot of the coordinates for each accession from the principle component analysis. Circles group accessions diverging from the main cluster.

The earliest reports of purple nutsedge in North and South America were made along the coast of South Carolina and Georgia in 1821 [23] and Brazil in 1842 [24]. Whether these were original points of entry into the Americas or from common or different points of origin is unknown. Purple nutsedge was collected from seven Caribbean islands (1879 to 1908) [24] and from the states of Alabama (1896) [24], California (1901 \& 1905) [25], Texas (1901) [26], and District of Columbia (1899) [27]. Hence there may have been several entry points into the USA but whether these entry points originated solely from within the USA is unknown.

The similarity among US and New World accessions which span $4180 \mathrm{~km}$ east to west supports the idea of origin from a single source within the USA and dissemination by tubers resulting in large clonal populations rather than convergent evolution to a common form [1] [7] [8] [28]. Furthermore, as observed in this study and that of DaSilva et al. [17], large collections of accessions from within a country exhibited little diversity. The growth conditions in the US, though suitable for vegetative growth, may not be suitable for abundant seed development. Seed isolated from purple nutsedge from several populations from California did not germinate [8]. The distinctly different RAPD marker patterns of California* from the other California and US accessions may indicate that this accession is more prone to sexual reproduction or formed a hybrid with other sedges. California ${ }^{*}$ may also have been a recent introduction from Southeastern Europe brought as a contaminant in tree crops, such as olive and citrus trees, which were imported into southern California from this region. Cluster analysis of a subsample of the accessions from this collection using simple sequence mi- 
crosatellite markers also showed limited diversity among US accessions and clustering of accessions from Sudan, Greece, and Brazil [19] as was observed here.

\section{Conclusion}

This study evaluated diversity among purple nutsedge accessions from 20 countries and 14 states using molecular markers and morphological traits. The collection spans the globe with accessions from Africa, the Middle East, Pacific Island nations and Pacific Rim countries as well as from South and North America, and it represents the largest collection assessed for diversity using cluster analysis. The data were consistent with the hypothesis that purple nutsedge may be divided into varieties or subspecies but not into new species. The diversity observed though calculable was narrow in that only two clades were found with an indication of a third clade possibly emerging on a global scale. Such a narrow separation likely reflects an asexual reproduction strategy across the globe. Clustering of molecular marker and morphological data each showed separation of New World (mainly US) from African and Middle Eastern countries (mainly Sudan, Tanzania, and Greece) and each of these clusters had accessions from Asian and Pacific Rim countries. The lack of consistent regional separation of some accessions such as New World accessions grouped with Mauritius, Thailand and Australia, may reflect the global distribution of purple nutsedge as an ancient trade commodity. The molecular tools used herein have provided further evidence for there being global, genetic variants among purple nutsedge accessions indicating that with time isolation may lead to more pronounced intraspecific variation.

\section{Author Contributions}

Writing-original draft preparation and editing, W. T. M. and R. R. K.; writing-review and editing, W. T. M. and J. D. R.; critical corrections, B. E. S. and C. T. B.

\section{Disclaimer}

Mention of trade names or commercial products in this article is solely for the purpose of providing specific information and does not imply recommendation or endorsement by the US Department of Agriculture, an equal opportunity provider and employer.

\section{Conflicts of Interest}

The authors declare no conflict of interest.

\section{References}

[1] Holm, L.G., Plucknett, D.L., Pancho, J.V. and Herberger, J.P. (1977) The World's Worst Weeds: Distribution, and Biology. University Press of Hawaii, Honolulu, HI. 
[2] Holm, L., Pancho, J.V., Herberger, J.P. and Plucknett, D.L. (1979) A Geographical Atlas of World Weeds. John Wiley and Sons, New York.

[3] Negbi, M. (1992) A Sweetmeat Plant, a Perfume Plant and Their Weedy Relatives: A Chapter in the History of Cyperus esculentus L. and C. rotundus L. Economic Botany, 46, 64-71. https://doi.org/10.1007/BF02985255

[4] Buckley, S., Usai. D., Jakob, T., Radini, A. and Hardy, K. (2014) Dental Calculus Reveals Unique Insights into Food Items, Cooking and Plant Processing in Prehistoric Central Sudan. PLoS ONE, 9, e100808.

https://doi.org/10.1371/journal.pone.0100808

[5] Kükenthal, G. (1935-1936) Cyperaceae-Scirpoideae-Cypereae. In: Engler, A. and Englemann, W., Eds., Das Pflanzenre, Leipzig, 1-671.

[6] Bryson, C.T. and Carter, R. (2008) The Significance of Cyperaceae as Weeds, In: Naczi, R.F.C. and Ford, B.A., Eds., Sedges: Uses, Diversity, and Systematics of the Cyperaceae, Monographs in Systematic Botany from the Missouri Botanical Garden, St Louis, MO, 15-101.

[7] Bendixen, L.E. and Nandihalli, U.B. (1987) Worldwide Distribution of Purple and Yellow Nutsedge (Cyperus rotundus and C. esculentus). Weed Technology, 1, 61-65. https://doi.org/10.1017/S0890037X00029158

[8] Thullen, R.J. and Keeley, P.E. (1979) Seed Production and Germination in Cyperus esculentus and C. rotundus. Weed Science, 27, 502-505.

https://doi.org/10.1017/S0043174500044489

[9] Neeser, C., Aguero, R. and Swanton C.J. (1997) Survival and Dormancy of Purple Nutsedge (Cyperus rotundus) Tubers. Weed Science, 45, 784-790. https://doi.org/10.1017/S0043174500088974

[10] Ranade, S.B. and Burns, W. (1925) The Eradication of Cyperus rotundus L. Memoirs of the Department of Agriculture in India. Botany Series, 13, 99-192.

[11] Tropicos (2019) Tropicos.org. Missouri Botanical Garden. Saint Louis. http://www.tropicos.org/Name/22200058

[12] Wills, G.D. (1998) Comparison of Purple Nutsedge (Cyperus rotundus) from around the World. Weed Technology, 12, 491-503. https://doi.org/10.1017/S0890037X00044201

[13] Schippers, P., Ter Borg, S. and Bos, J.J. (1995) A Revision of the Infraspecific Taxonomy of Cyperus esculentus (Yellow Nutsedge) with an Experimentally Evaluated Character Set. Systematic Botany, 20, 461-481. https://doi.org/10.2307/2419804

[14] Okoli, C.A.N., Shilling, D.G., Smith, R.L. and Bewick, T.A. (1997) Genetic Diversity in Purple Nutsedge (Cyperus rotundus L.) and Yellow Nutsedge (Cyperus esculentus L.). Biological Control, 8, 111-118. https://doi.org/10.1006/bcon.1996.0490

[15] Pereira, W., Tessmann, D.J. and Charudattan, R. (2000) Analysis of Genetic Variation in Cyperus rotundus Accessions Using Molecular Markers. Third International Weed Science Conference, Foz do Iguassu, Brazil, 47.

[16] Komai, K., Tang, C.-S. and Nishimoto, R.K. (1991) Chemotypes of Cyperus rotundus in Pacific Rim and Basin: Distribution and Inhibitory Activities of Essential Oils. Journal of Chemical Ecology, 17, 1-8. https://doi.org/10.1007/BF00994417

[17] Da Silva, C.A.R., Mori, E.S., Velini, E.D. and Martins, D. (2000) Identification of Purple Nutsedge (Cyperus rotundus L.) by Isoenzymes. Third International Weed Science Conference, Foz do Iguassu, Brazil, 47-48.

[18] Tayyar, R.I., Nguyen, J.H.T. and Holt, J.S. (2003) Genetic and Morphological Analysis of Two Novel Nutsedge Biotypes from California. Weed Science, 51, 731-739. 
https://doi.org/10.1614/P2002-131

[19] Arias, R.S., Molin, W.T., Ray, J.D., Peels, M.D. and Scheffler, B.E. (2011) Isolation and Characterization of the First Microsatellite Markers for Cyperus rotundus. Weed Research, 51, 451-460. https://doi.org/10.1111/j.1365-3180.2011.00861.x

[20] SERNEC Data Portal (2019) http://sernecportal.org/portal/index.php

[21] Doyle, J.J and Doyle, J.L. (1987) A rapid DNA Isolation Procedure for Small Quantities of Fresh Leaf Tissue. Phytochemical Bulletin, 19, 11-15.

[22] (2012) Data Analysis for This Paper Was Generated Using SAS Software. SAS Institute Inc., SAS Campus Drive, Cary, NC.

[23] Elliot, S. (1821) A Sketch of the Botany of South Carolina and Georgia. J.R. Scheneck, Charleston. https://doi.org/10.5962/bhl.title.9508

[24] The New York Botanical Garden Virtual Herbarium http://sciweb.nybg.org/science2/vii2.asp

[25] Consortium of California Herbaria http://ucjeps.berkeley.edu/consortium/data_use_terms.html

[26] Flora of Texas Database http://w3.biosci.utexas.edu/

[27] Smithsonian, National Museum of Natural History http://botany.si.edu/DCFlora/dcspecimens/spec_report.cfm

[28] Horowitz, M. (1972) Growth, Tuber Formation and Spread of Cyperus rotundus L. from Single Tubers. Weed Research, 12, 348-363. https://doi.org/10.1111/j.1365-3180.1972.tb01229.x 